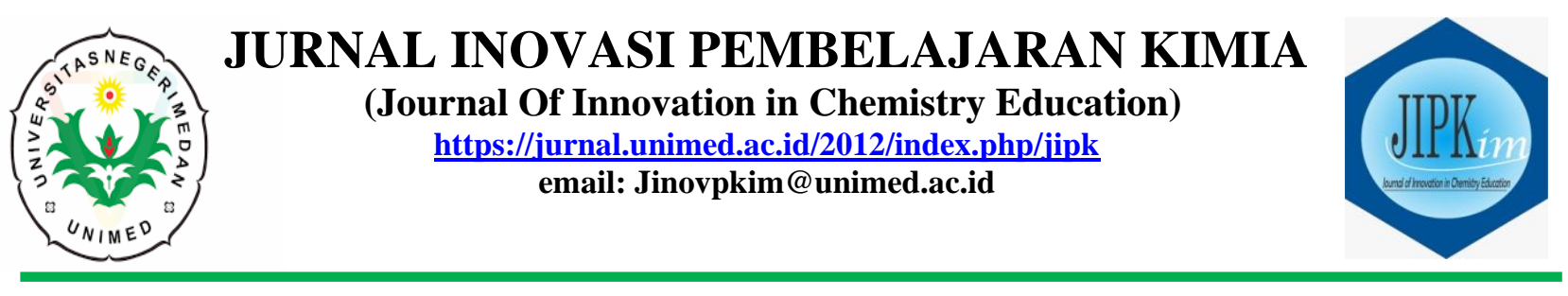

\title{
Implementasi Bahan Ajar Hidrolisis Garam Terintegrasi Nilai-Nilai Islami dengan Model Problem Based Learning untuk Meningkatkan Hasil Belajar Siswa Ditinjau dari Minat Belajar Siswa
}

\author{
Indah Sundari Zega ${ }^{\mathrm{a}, *}$, Ayi Darmana ${ }^{\mathrm{a}}$ \\ ${ }^{a}$ Program Studi Pendidikan Kimia, Universitas Negeri Medan, Medan \\ *Alamat Korespondensi: indahsundarizega@gmail.com
}

Abstract:

This study aims to find out: (1) A significant difference in students 'learning outcomes was taught using the integrated chemicals of Islamic values and which were taught using the students ' high school chemistry teaching book through The learning model of the hydrolysis of salt. (2) A significant difference in the students 'Islamic attitudes before and after being taught by using integrated chemical materials of Islamic values. (3) A significant relationship between Islamic attitudes and increasing student learning outcomes. The data analysis technique is conducted with the Independent Sample TTest, Paired Sample T-Test, Correlation and Anava two paths. Research results can be concluded that: (1) There is a significant difference in learning outcomes among students taught using integrated chemicals Islamic values and which are taught using the students 'high school chemistry teaching book through the PBL learning model in the subject matter Hydrolysis salt. (2) There are significant differences in the students' Islamic attitudes before and after being taught using the integrated chemical materials of Islamic values. (3) There is a significant correlation of spiritual value with the increase of student learning outcomes which are taught using the integrated chemistry module of Islamic values.

Keywords:

Learning Outcomes of Chemistry, Islamic Values, Teaching Materials, Learning Interests

\section{PENDAHULUAN}

\begin{tabular}{llr}
\multicolumn{1}{c}{ Pendidikan Nasional berfungs } \\
mengembangkan kemampuan & dan \\
membentuk watak serta peradapan & bangs \\
yang bermartabat dalam rangk
\end{tabular} mencerdaskan kehidupan bertujuan untuk berkembangnya potensi peserta didik agar menjadi manusia yang beriman dan bertaqwa kepada Tuhan Yang Maha Esa, berakhlak mulia, sehat, berilmu, cakap kreatif, mandiri dan menjadi warga Negara yang demokratis serta bertanggung jawab (UU RI Nomor 20 Tahun 2003). Untuk mencapai tujuan pendidikan nasional tersebut, pada Undang-Undang Dasar (UUD) 1945 (amandemen) Pasal 31 Ayat 3 dijelaskan bahwa pengembangan pendidikan nasional diorientasikan untuk meningkatkan keimanan dan ketaqwaan kepada Tuhan Yang Maha Esa serta akhlak mulia dalam rangka mencerdaskan kehidupan bangsa. Pada Pasal 31 Ayat 5 juga dijelaskan bahwa pendidikan nasional ditujukan untuk memajukan ilmu pengetahuan dan teknologi dengan menjunjung tinggi nilai-nilai agama dan persatuan bangsa untuk kemajuan peradaban serta kesejahteraan umat manusia (Hikmah, 2013).

Menurut Depdiknas (2010) Kurikulum 2013 terdiri dari dua kompetensi pokok yakni kompetensi inti dan kompetensi dasar. Kompetensi inti-1 (KI-1) untuk kompetensi 
inti sikap spiritual, kompetensi inti-2 (KI-2) untuk kompetensi inti sikap sosial, kompetensi inti-3 (KI-3) untuk kompetensi inti pengetahuan, Kompetensi inti-4 (KI-4) untuk kompetensi inti keterampilan. Dari keempat kompetensi diatas, kompetensi spiritual merupakan kompetensi yang sangat penting untuk peserta didik. Kompetensi spiritual merupakan suatu nilai yang bersifat religius, dengan kata lain pikiran, perkataan dan tindakan seseorang harus berdasarkan nilai-nilai ketuhanan atau berdasarkan ajaran agama. Dengan adanya kompetensi spiritual peserta didik diharapkan mampu menjadi manusia yang memiliki akhlak mulia dan taat terhadap nilai-nilai agama ajarannya. Jumini \& Wahyudi (2015) mengatakan pengajaran yang menggunakan pendidikan spiritual, pada pembelajaran di kelas diharapkan nantinya siswa mempunyai karakter keagamaan, ini sesuai dengan yang diharapkan oleh Undang-Undang Sistem Pendidikan Nasional tahun 2003.

Penyampaian nilai-nilai spiritual dalam pelajaran kimia dapat dilakukan melalui penyusunan bahan ajar yang disusun sedemikian rupa sehingga nilai-nilai spiritual terintegrasi didalamnya (Saputro, 2011). Pembelajaran mata pelajaran kimia bertujuan membentuk "sikap positif terhadap kimia dan menyadari keteraturan-keteraturan alam serta mengagungkan Tuhan Yang Maha Esa". "Sikap positif terhadap kimia dan menyadari keteraturan alam" dapat dicapai sebagai hasil dari penyelidikan, yang mengantarkan kepada suatu kesadaran atau keyakinan bahwa alam ini memiliki hukum-hukum tersebut (sunatullah) dan pasti ada yang mengatur, menetapkan, pencipta dan pemiliknya. Pengagungan terhadap Allah Tuhan Yang Maha Esa diharapkan muncul seiring dengan pengagungan terhadap ciptaan-Nya yang indah, teratur sehingga memudahkan untuk dipelajari (Darmana, 2016).

Dalam ilmu kimia banyak terdapat materimateri pelajaran yang mengandung nilai-nilai keindahan dan keteraturan yang pada akhirnya mengarah kepada peng-Agungan sang pencipta serta jika dapat menggali lebih dalam lagi hakikat makna dibalik peristiwaperistiwa kimia tersebut, maka akan diperoleh banyak sekali nilai-nilai religiusnya yang sangat diperlukan oleh para siswa sebagai bekal hidup di dunia (Djudin, 2011). Dengan adanya pengintegrasian nilai agama terhadap suatu konsep pembelajaran kimia diharapkan dapat memberikan pengaruh positif dalam rangka menanamkan nilai-nilai keimanan siswa serta memadukannya dalam ilmu pengetahuan dan teknologi sehingga dapat membentuk dan membina sikap positif siswa dalam kehidupan sehari-hari. Kombinasi sains dan agama merupakan kombinasi konsep yang tepat untuk memahami alam (Marsonet, 2012).

Rochman (2010) mengatakan bahwa perlu dirumuskan secara jelas bagaimana nilai Islam dalam program dan praktek pembelajaran disemua pelajaran di lingkungan sekolah. Penerapan nilai Agama Islam dalam proses pembelajaran dapat menimbulkan kesadaran terhadap nilai kebaikan dan keselamatan. Nilai inilah yang akan menciptakan kebaikan antar sesama manusia atau sains berbasis humaniora. Kebaikan yang bersumber dari Allah SWT dalam pembelajaran akan membentuk akhlak mulia.

Ada teori yang mengatakan bahwa hasil belajar dipengaruhi oleh beberapa faktor. Menurut Slameto (2010) factor-faktor yang mempengaruhi belajar banyak jenisnya, tetapi dapat digolongkan menjadi dua golongan saja, yaitu faktor intern dan factor ekstern. Faktor internal yang dimaksud adalah faktor jasmani seperti kesehatan dan faktor psikologis seperti bakat, minat, intelegensi, dan kesiapan. Dari beberapa faktor psikologis yang telah disebutkan salah satunya adalah minat. Orang yang tidak memiliki minat pada mata pelajaran tertentu sulit untuk mencapai keberhasilan belajar yang optimal. Minat sebagai pernyataan psikis yang menunjukkan adanya pemusatan perhatian terhadap suatu materi pelajaran karena obyek tersebut menarik bagi dirinya. Minat belajar adalah kecenderungan hati yang tinggi terhadap suatu gairah keinginan 
untuk suatu perubahan yang terjadi pada seseorang dalam melaksanakan kegiatan (belajar) amat bergantung dari kapasitas yang dimiliki. Pemusatan perhatian dalam proses pembelajaran sangat diperlukan, karena kehadiran minat belajar dalam pribadi seseorang akan merangsang keinginan untuk belajar yang lebih besar (Muldayanti, 2013).

Agar minat belajar siswa dapat tumbuh dan berkembang secara baik, guru perlu meningkatkan minat belajar siswa dalam pembelajaran dengan menerapkan model pembelajaran. Salah satunya yaitu model pembelajaran Problem Based Learning. Problem Based Learning dapat menghasilkan generasi penerus bangsa yang produktif, kreatif, inovatif, dan berkarakter. Problem Based Learning merupakan suatu pendekatan pembelajaran dimana siswa dihadapkan pada masalah autentik (nyata) sehingga diharapkan mereka dapat menyusun pengetahuannya sendiri, menumbuh kembangkan keterampilan tingkat tinggi dan inkuiri, memandirikan siswa, dan meningkatkan kepercayaan dirinya (Trianto, 2010).

Okmarisa, dkk, (2016) melakukan penelitian tentang implementasi bahan ajar kimia terintegrasi nilai-nilai spiritual dengan model pembelajaran Problem Based Learning berorientasi kolaboratif untuk meningkatkan hasil belajar siswa menunjukkan bahwa dalam penelitian ini pengintegrasian nilai-nilai spiritual dilakukan dengan menyisipkan nilai-nilai spiritual kedalam bahan ajar yang disesuaikan dengan materi ikatan kimia. Peningkatan sikap spiritual berdasarkan angket penilaian yang diperoleh 0,45 dengan kategori sedang. Sehingga dapat disimpulkan bahwa bahan ajar terintegrasi nilai spiritual dapat menumbuh kembangkan sikap spiritual pada siswa. Serta terdapat hubungan antara nilai spiritual terhadap peningkatan hasil belajar siswa yang diajarkan dengan bahan ajar kimia terintegrasi nilai spiritual karena harga Sig. < a $(0,002<0,05$. Maka Ha diterima dimana $\mathrm{R}=0,508$ dengan kriteria Agak rendah.
Hasil penelitian lainnya oleh Dermawan (2016) tentang pengembangan modul kimia terintegrasi nilai - nilai Islami pada pokok bahasan minyak bumi untuk siswa SMA dikategorikan valid tanpa revisi berdasarkan angket penilaian BSNP. Oleh karena itu, diperlukan pengembangan bahan ajar lainnya agar lebih variatif dan fungsional. Bahan ajar yang memanfaatkan ayat-ayat Allah SWT. Di dalam Alquran dan Hadis Rasulullah SAW sehingga dapat mencapai KI-1 pada pembelajaran kimia.

Penerapan model pembelajaran Problem Based Learning (PBL) dan disertai pengintegrasian nilai-nilai islami didalam pembelajaran kimia pada materi Hidrolisis Garam diharapkan mampu meningkatkan hasil belajar siswa dalam kognitif dan sikap Spiritualnya. Sehingga akan tercipta insan yang cerdas serta berbudi pekerti yang baik dengan beriman kepada Tuhan Yang Maha Esa.

Penelitian ini dilakukan untuk mengetahui: 1) Perbedaan yang signifikan hasil belajar siswa yang diajarkan menggunakan bahan kimia terintegrasi nilainilai islami dan yang diajarkan menggunakan buku ajar kimia SMA/MA pegangan siswa melalui model pembelajaran PBL pada pokok bahasan Hidrolisis Garam. (2) Perbedaan yang signifikan sikap islami siswa sebelum dan sesudah diajarkan dengan menggunakan bahan ajar kimia terintegrasi nilai-nilai Islami. (3)Hubungan yang signifikan antara sikap Islami dengan peningkatan hasil belajar siswa. (4)Pengaruh minat belajar terhadap hasil belajar siswa. (5)Apakah ada pengaruh jenis bahan ajar terhadap hasil belajar siswa. (6)Pengaruh minat belajar terhadap sikap islami siswa. (7)Interaksi antara jenis bahan ajar dan minat belajar terhadap hasil belajar siswa.

\section{METODE}

Penelitian ini telah dilaksanakan di MAN 1 Medan kelas XI semester genap tahun ajaran 2018/2019 pada materi hidrolisis garam. Populasi dalam penelitian ini adalah seluruh siswa MAN 1 Medan kelas XI semester genap tahun ajaran 2018/2019 
dengan kurikulum yang sama. Penentuan sampel penelitian dilakukan dengan teknik random sampling, dimana sampel yang digunakan dalam penelitian ini adalah sebanyak dua kelas, yakni satu kelas sebagai eksperimen I yang dibelajarkan dengan modul pegangan siswa dan satu kelas eksperimen II dibelajarkan dengan modul terintegrasi nilai-nilai islami pada materi Hidrolisis Garam dengan model PBL. Instrumen penelitian berupa tes objektif hasil belajar, serta instrumen angket sikap islami . Sebelum instrumen tes pilihan ganda digunakan, instrumen tersebut diujicobakan pada siswa yang telah mempelajari materi hidrolisis garam yakni siswa MAN 1 Medan untuk diuji validitas dan reliabilitas butir soal. Uji validitas dilakukan dengan software SPSS for Windows seri 20.0 melihat hasil corrected item-total correlation.

Analisis data dilakukan menggunakan bantuan program SPSS 20.0 for windows. Teknik analisa data dilakukan dengan rumus gain ternormalisasi untuk melihat peningkatan hasil belajar selanjutnya dilakukan dengan uji Independent Sample Ttest, Correlation dan Uji Anova Two Ways pada program SPSS 20 for windows dengan taraf signifikan 0,05. Penggunaan teknik analisis ini memerlukan persyaratan yang harus dipenuhi yaitu normalitas dan homogenitas. Uji normalitas menggunakan SPSS 20.0 for windows dengan pendekatan Kolmogorov-Smirnov dan homogenitas dilakukan dengan pendekatan Levene's Test.

\section{HASIL DAN PEMBAHASAN}

\section{Peningkatan Hasil Belajar}

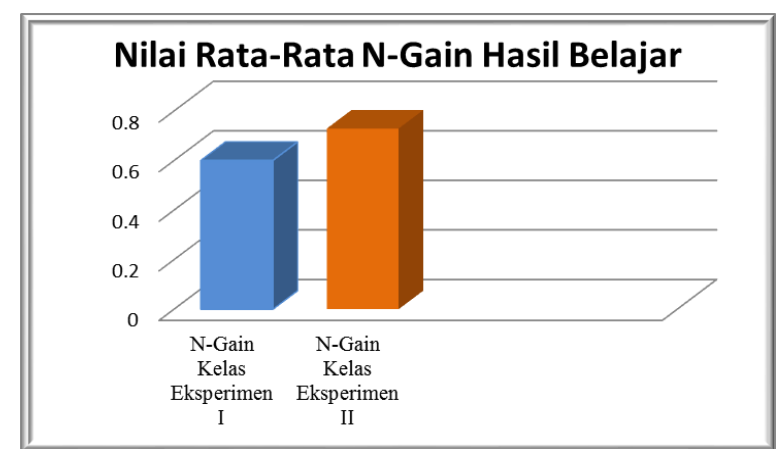

Gambar 1. Perbandingan Nilai Rata-rata NGain Hasil Belajar
Secara keseluruhan terdapat perbedaan antara kelas eksperimen I yaitu siswa yang diajarkan menggunakan buku ajar kimia SMA/MA pegangan siswa dan kelas eksperimen II siswa yang diajarkan menggunakan bahan ajar terintegrasi nilainilai Islami dengan model Problem Based Learning pada pokok bahasan hidrolisis garam. Perbedaan dapat dilihat pada Gambar 1. yaitu nilai $\mathrm{n}$-Gain yang diperoleh pada peningkatan hasil belajar dimana pada kelas eksperimen I sebesar 0,5830 dengan persen peningkatan hasil belajar 58,30 \% dan pada kelas eksperimen II sebesar 0,7278 dengan persen peningkatan hasil belajar 72,78\% pada pokok bahasan hidrolisis garam kelas XI semester 2 di MAN 1 Medan.

Berdasarkan hasil pengujian hipotesis, melalui pengujian data dengan SPSS 20.0 for windows diketahui bahwa bahan ajar terintegrasi nilai-nilai Islami berpengaruh terhadap hasil belajar siswa. Hasil belajar siswa yang diajarkan menggunakan bahan ajar kimia terintegrasi nilai-nilai Islami lebih tinggi daripada hasil belajar kimia siswa yang diajarkan menggunakan buku ajar kimia SMA/MA pegangan siswa pada pokok bahasan hidrolisis garam dengan harga Sig. (2-tailed) yaitu 0,000 lebih kecil dari 0,05 (tingkat kesalahan $5 \%$ tingkat kepercayaan 95\%).

Dari penjelasan diatas artinya terdapat perbedaan hasil belajar siswa yang diajarkan menggunakan bahan ajar terintegrasi nilainilai Islami dengan buku ajar kimia SMA/MA pegangan siswa pada pokok bahasan hidrolisis garam. Perbedaan ini dipengaruhi bahan ajar yang digunakan dimana pada bahan ajar kimia terintegrasi nilai-nilai Islami mendorong kecerdasan spiritual siswa dengan menambah keimanan sehingga siswa membentuk sikap positif terhadap pembelajaran kimia dengan menyadari keteraturan dan keindahan alam serta mengagungkan kebesaran Tuhan Yang Maha Esa. Hal ini sesuai dengan pendapat Saputro (2011) yang menyatakan siswa tertarik untuk mempelajari kimia lebih mendalam karena ilmu kimia bukanlah kumpulan rumus-rumus dan persamaan 
reaksi yang harus dihapal untuk kemudian dilupakan setelah lulus sekolah, melainkan ilmu yang mempelajari keindahan keteraturan hukum-hukum Ilahi di alam semesta.

Bahan ajar berbasis nilai-nilai islami dapat menumbuhkan sikap positif siswa menjadi pribadi yang cerdas, ikhlas, disiplin dan memiliki kesadaran yang tinggi sehingga siswa yang memiliki kecerdasan spiritual memiliki motivasi yang kuat untuk memperluas pengetahuannya melalui proses pembelajaran. Siswa yang memiliki kecerdasan spiritual akan bertanggung jawab dengan pekerjaannya. Hal inilah yang membuat hasil belajar siswa yang menggunakan bahan ajar terintegrasi nilainilai islami lebih tinggi dibandingkan dengan yang menggunakan buku ajar kimia SMA/MA pegangan siswa pada pokok bahasan hidrolisis garam.

Banyak studi yang mengisaratkan pentingnya pengintegrasian aspek spiritual dalam pembelajaran, diantaranya pendapat Darmana (2013) yang berpendapat mengintegrasikan nilai-nilai tauhid dalam materi ajar tidak akan mengurangi kualitas tingkat ilmiah dari sains itu sendiri, bahkan merupakan upaya yang tepat karena berarti mengembalikan bersatunya antara syariat dan hakikat.

\section{Perbedaan Sikap Islami Siswa Sebelum dan Sesudah Diajarkan dengan Menggunakan Bahan Ajar Kimia Terintegrasi Nilai-Nilai Islami}

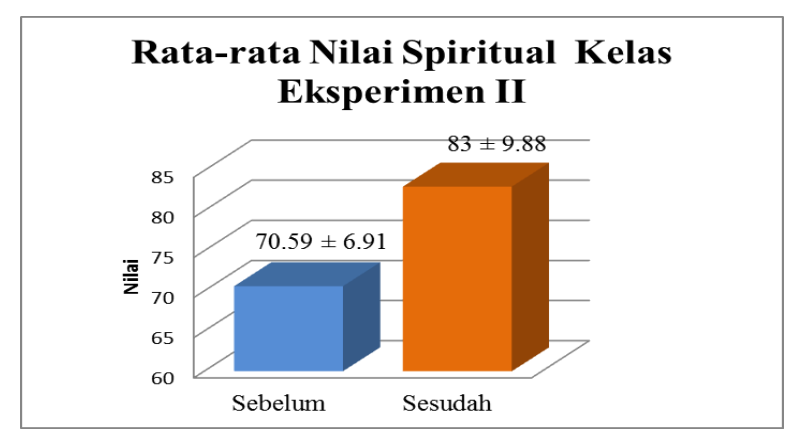

Gambar 2. Perbandingan Nilai Rata-rata Nilai Spiritual Kelas Eksperimen II

Pada dasarnya Madrasah Aliyah Negeri 1 Medan sudah menginternalisasi nilai spiritual pada siswa melalui peraturan-peraturan baik secara tertulis maupun tidak tertulis. Diantaranya sikap spiritual adalah sebelum pelajaran dimulai berdoa terlebih dahulu dan dilanjutkan pembacaan ayat suci Al- Qur'an. Sehingga siswa terbiasa berdoa ketika hendak melakukan apapun. Hanya saja nilai spiritual belum diintegrasikan dalam setiap pokok bahasan pada pembelajaran dari setiap mata pelajaran.

Pada Gambar 2. terdapat peningkatan sikap spiritual sebelum dan sesudah diberi perlakuan dengan bahan ajar terintegrasi nilai-nilai Islami dari 70,59 menjadi 83,00. Artinya terdapat perbedaan sikap Islami siswa sebelum dan sesudah diberikan perlakuan yang diajarkan menggunakan bahan ajar terintegrasi nilai-nilai Islami pada pokok bahasan hidrolisis garam.

Hal ini karena bahan ajar yang telah dikembangkan dilengkapi dengan unsurunsur religius dan memberikan energi positif kepada siswa. Pembelajaran menggunakan bahan ajar terintegrasi nilai-nilai Islami memberikan respons dan tanggungjawab berdasarkan kadar kecerdasan spiritual yang dimiliki masing-masing siswa yang efektif meningkatkan hasil belajar dan kecerdasan spiritual sehingga siswa tidak hanya menekankan segi-segi pengetahuan kognitif intelektual saja tetapi juga menumbuhkan segi-segi kualitas psikomotorik dan kesadaran spiritual yang reflektif dalam kehidupan sehari-hari untuk mendidik hati dan budi pekerti siswa. Hal ini sesuai dengan hasil penelitian Saputro (2011) yang menyatakan pengintegrasian nilai-nilai religius yang bersumber dari ayat-ayat AlQuran dalam buku pelajaran kimia dapat menanamkan pendidikan islami (karakter insan mulia) kepada siswa. Hal ini juga senada dengan yang diungkapkan Djudin (2011) yang menyatakan menyisipkan nilainilai agama dalam pelajaran sains merupakan ikhtiar nyata untuk mewujudkan tujuan pembelajaran IPA agar siswa mengagungkan dan mengimani Sang Pencipta. 
Hubungan Nilai Spiritual Terhadap Hasil Belajar

Berdasarkan hasil uji hipotesis yang dilakukan dengan SPSS 20.0 for windows. Kriteria yang berlaku dalam pengujian data menggunakan SPSS 20.0 for windows yaitu jika Sig. $<0,05$ maka $\mathrm{H}_{\mathrm{a}}$ diterima. Dari hasil pengujian nilai Sig. yang diperoleh lebih kecil dari 0,05 yaitu 0,020, sehingga dapat disimpulkan bahwa hipotesis diterima. Artinya terdapat korelasi nilai Islami dengan peningkatan hasil belajar siswa yang diajarkan menggunakan bahan ajar terintegrasi nilai-nilai Islami. Besarnya korelasi atau hubungan nilai-nilai Islami terhadap peningkatan hasil belajar siswa dapat dilihat dari Pearson Correlation. Besarnya nilai korelasi adalah 0,366. Jika dilihat dari interval hubungan korelasi maka termasuk rentang korelasi rendah.

Dari lembar angket spiritual yang diberikan kepada siswa, siswa dengan hasil belajar yang baik cenderung memiliki nilai spiritual yang tinggi, dan siswa yang hasil belajar yang rendah memiliki nilai spiritual yang rendah. Hal ini senada dengan yang dikatakan Jumini \& Wahyudi (2015) yang berpendapat bahwa ilmu agama dapat dijadikan penyeimbang dari ilmu sains, karena jika ilmu sains tidak diseimbangkan dengan ilmu agama maka akan menghasilkan kemajuan secara fisik tetapi kering dalam aspek spiritual. Kombinasi sains dan agama merupakan kombinasi konsep yang tepat untuk memahami alam (Marsonet, 2012).

\section{Pengaruh Minat Belajar Terhadap Hasil Belajar Siswa}

Secara keseluruhan terdapat perbedaan minat belajar tinggi dan rendah terhadap hasil belajar siswa pada kelas ekperimen I dan eksperimen II. Pada pengujian data dengan SPSS 20.0 for windows, jika Sig. < 0,05 , maka $\mathrm{H}_{\mathrm{a}}$ diterima. Sedangkan jika Sig. $>0,05$, maka $\mathrm{H}_{\mathrm{a}}$ ditolak. Dari hasil pengujian nilai Sig. yang diperoleh lebih kecil dari 0,05 yaitu 0,000 , sehingga dapat disimpulkan bahwa hipotesis diterima. Artinya terdapat pengaruh minat belajar siswa terhadap hasil belajar antara yang diajarkan menggunakan bahan ajar terintegrasi nilai-nilai Islami dan yang diajarkan menggunakan buku ajar kimia SMA/MA pegangan siswa pada pokok bahasan hidrolisis garam dengan Model Problem Based Learning .

Dari lembar angket minat belajar yang diberikan kepada siswa, siswa dengan minat belajar tinggi cenderung memiliki hasil belajar yang tinggi, dan siswa yang memiliki minat belajar yang rendah memiliki hasil belajar yang rendah pula. Hal ini senada dengan yang dikatakan Hidayat (2010) menyatakan bahwa pada dunia pendidikan, siswa yang memiliki minat belajar yang tinggi maka akan mempunyai energi yang lebih untuk melakukan kegiatan belajar. Seseorang yang memiliki minat terhadap sesuatu hal, akan merasa tertarik dan terdorong untuk melakukan kegiatan yang berkaitan dengan hal tersebut. Dengan adanya rasa senang dan tertarik akan menggunakan apa saja yang dimilikinya untuk melibatkan diri dalam kegiatan tersebut agar mendapat hasil sesuai yang diharapkan. Ketika siswa memiliki minat belajar tinggi, maka siswa tersebut akan mendapatkan prestasi belajar tinggi, begitu juga sebaliknya (Muldayanti, 2013).

\section{Pengaruh Jenis Bahan Ajar Terhadap Hasil Belajar Siswa}

Bahan Ajar merupakan seperangkat materi yang disusun secara sistematis baik tertulis maupun tidak, sehingga tercipta suatu lingkungan/suasana yang memungkinkan siswa untuk belajar.

Pada pengujian data dengan SPSS 20.0 for windows, jika Sig. $<0,05$, maka $\mathrm{H}_{\mathrm{a}}$ diterima. Sedangkan jika Sig. > 0,05, maka $\mathrm{H}_{\mathrm{a}}$ ditolak. Dari hasil pengujian nilai Sig. yang diperoleh lebih kecil dari 0,05 yaitu 0,005 , sehingga dapat disimpulkan bahwa hipotesis diterima. Artinya terdapat pengaruh jenis bahan ajar terhadap hasil belajar antara yang diajarkan menggunakan bahan ajar terintegrasi nilainilai Islami dan yang diajarkan menggunakan buku ajar kimia SMA/MA pegangan siswa pada pokok bahasan hidrolisis garam dengan Model Problem Based Learning. 
Berdasarkan hasil pengujian hipotesis, melalui pengujian data dengan SPSS 20.0 for windows diketahui bahwa bahan ajar terintegrasi nilai-nilai Islami berpengaruh terhadap hasil belajar siswa. Hasil belajar siswa yang diajarkan menggunakan bahan ajar kimia terintegrasi nilai-nilai Islami lebih tinggi daripada hasil belajar kimia siswa yang diajarkan menggunakan buku ajar kimia SMA/MA pegangan siswa pada pokok bahasan hidrolisis garam.

Perbedaan ini dipengaruhi oleh bahan ajar yang digunakan, sesuai dengan penelitian Sugiarti (2013) yaitu penggunaan media pengajaran yang berbeda dengan menggunakan bahan ajar dapat menghasilkan perbedaan hasil belajar dari setiap kelas. Dimana pada bahan ajar kimia terintegrasi nilai-nilai Islami mendorong kecerdasan spiritual siswa dengan menambah keimanan sehingga siswa membentuk sikap positif terhadap pembelajaran kimia dengan menyadari keteraturan dan keindahan alam serta mengagungkan kebesaran Tuhan Yang Maha Esa. Hal ini sesuai dengan pendapat Saputro (2011) yang menyatakan siswa tertarik untuk mempelajari kimia lebih mendalam karena ilmu kimia bukanlah kumpulan rumus-rumus dan persamaan reaksi yang harus dihapal untuk kemudian dilupakan setelah lulus sekolah, melainkan ilmu yang mempelajari keindahan keteraturan hukum-hukum Ilahi di alam semesta.

\section{Pengaruh Minat Belajar Terhadap Sikap Islami Siswa}

Minat merupakan rasa suka dan rasa ketertarikan pada suatu hal atau aktivitas, tanpa ada yang menyuruh. Dalam hal ini seorang siswa mempunyai ketertarikan pada suatu hal yang ia sukai atau senangi, sehingga ia mampu melakukan sesuatu yang dirinya mau tanpa disuruh oleh orang lain.

Pada pengujian data dengan SPSS 20.0 for windows, jika Sig. $<0,05$, maka $\mathrm{H}_{\mathrm{a}}$ diterima. Sedangkan jika Sig. > 0,05, maka Ha ditolak. Dari hasil pengujian nilai Sig. yang diperoleh lebih besar dari 0,05 yaitu 0,567 , sehingga dapat disimpulkan bahwa hipotesis keenam ditolak. Artinya tidak terdapat pengaruh minat belajar siswa terhadap sikap islami siswa yang diajarkan menggunakan bahan ajar terintegrasi nilai-nilai Islami pada pokok bahasan hidrolisis garam dengan Model Problem Based Learnig.

Dari lembar angket minat belajar yang diberikan kepada siswa, siswa dengan minat belajar tinggi belum tentu memiliki sikap spiritual yang tinggi, dan siswa yang memiliki minat belajar yang rendah belum tentu juga memiliki sikap spiritual yang rendah. Berdasarkan hasil penelitian tersebut menunjukkan bahwa untuk meningkatkan sikap spiritual siswa tidak berdasarkan tinggi rendahnya minat belajar siswa. Akan tetapi, jika siswa mempunyai sikap spiritual yang tinggi, maka minat belajar siswa tersebut juga cenderung tinggi. Hal ini senada dengan pernyataan Basuki (2015) yang menyatakan seorang siswa yang mempunyai kecerdasan spiritual/ sikap spiritual yang tinggi maka ia akan mempunyai rasa optimis yang tinggi karena menyadari bahwa setiap perilakunya merupakan suatu bentuk ibadah yang akan mendapatkan balasan dari Tuhan. Sehingga hal ini akan membangkitkan minat belajar atau menjadi penggerak dalam diri siswa untuk melakukan kegiatan belajar. Arfiyah, dkk (2016) juga menunjukkan bahwa kompendium al-Quran yang menumbuhkan sikap spiritual siswa pada pembelajaran Problem Based Learning (PBL) berpengaruh terhadap minat belajar siswa.

Dapat disimpulkan bahwa tidak terdapat pengaruh minat belajar terhadap sikap spiritual siswa, akan tetapi sikap spiritual akan mempengaruhi minat belajar siswa sehingga hasil belajar siswa menjadi lebih baik. Ini bermakna, semakin tinggi sikap spiritual seorang siswa, maka akan memiliki kesadaran yang tinggi untuk belajar artinya mampu menghidupkan minat belajar siswa dalam belajar sehingga membantu siswa dalam mencapai prestasi belajar yang diinginkan. 
Interaksi Bahan Ajar dengan Minat Belajar Terhadap Hasil Belajar

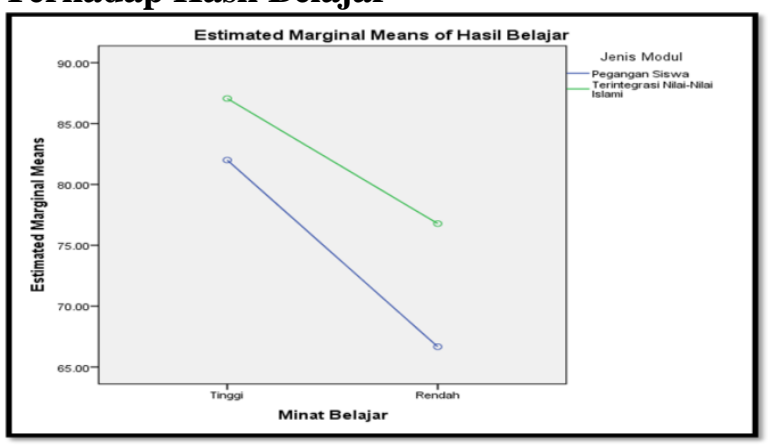

Gambar 3. Interaksi Jenis Bahan Ajar dan Minat Belajar Terhadap Hasil Belajar

Interaksi dapat diartikan suatu kerjasama dua variabel bebas atau lebih dalam mempengaruhi suatu variabel terikat. Interaksi terjadi manakala suatu variabel bebas memiliki efek-efek yang berbeda terhadap suatu variabel terikat pada berbagai tingkat dari suatu variabel bebas lainnya (Muldayanti, 2013).

Interaksi bahan ajar dengan minat terhadap hasil belajar siswa di uji dengan program SPSS 20.0 for wondows. Pada pengujian data dengan SPSS 20.0 for windows, jika Sig. $<0,05$, maka $\mathrm{H}_{\mathrm{a}}$ diterima. Sedangkan jika Sig. > 0,05, maka Ha ditolak. Dari hasil pengujian nilai Sig. yang diperoleh lebih besar dari 0,05 yaitu 0,340, sehingga dapat disimpulkan bahwa hipotesis ditolak. Dari hasil Gambar 3. terlihat bahwa tidak adanya interaksi karena pola garis perkiraan jarak rata-rata hasil belajar siswa pada jenis bahan ajar dan minat belajar kategori tinggi dan rendah adalah sama. Artinya tidak terdapat potongan garis/ persilangan garis yang ditunjukkan oleh Gambar 3. Jadi, dapat disimpulkan bahwa tidak terdapat interaksi antara jenis bahan ajar dan minat belajar siswa terhadap hasil belajar siswa. Hal ini berarti bahwa jenis bahan ajar, minat belajar hanya berpengaruh secara simultan terhadap hasil belajar siswa. Bahan ajar pembelajaran dan minat belajar siswa mempengaruhi hasil belajar siswa secara independent.

Pembelajaran menggunakan bahan ajar kimia terintegrasi nilai-nilai islami lebih baik daripada menggunakan bahan ajar pegangan siswa. Untuk minat belajar siswa, semakin tinggi minat siswa maka semakin tinggi pula hasil belajar siswa yang dicapai. Sehingga apapun modul yang digunakan, siswa dengan minat tinggi akan memiliki hasil belajar yang lebih baik dari siswa dengan minat rendah. Dapat disimpulkan bahwa apapun minat siswa baik tinggi dan rendah, siswa yang diajar dengan bahan ajar terintegrasi nilainilai islami dengan model Problem Based Learning memiliki hasil belajar yang lebih baik daripada siswa yang diajarkan dengan bahan ajar pegangan siswa dengan model Problem Based Learning. Secara mandiri, minat belajar siswa berpengaruh terhadap hasil belajar siswa tetapi setelah berinteraksi dengan jenis bahan ajar yang digunakan, minat siswa tidak berpengaruh terhadap prestasi belajar siswa. Tidak adanya interaksi antara jenis bahan ajar pembelajaran dengan minat terhadap hasil belajar siswa pada materi hidrolisis garam dapat dikarenakan faktor lain, selain minat yang juga mempengaruhi hasil belajar siswa pada materi hidrolisis garam. Faktor lainnya dapat dipengaruhi oleh faktor internal dan faktor eksternal peserta didik dalam proses pembelajaran seperti sikap spiritual siswa. Sejalan dengan penelitian Budi (2013), yang mengatakan bahwa faktor yang mempengaruhi prestasi belajar siswa antara lain bakat, motivasi, sikap siswa, kesehatan, kondisi lingkungan kelas sehingga tidak terdapat interaksi antara metode pembelajaran dengan minat belajar siswa pada materi struktur atom dan sistem periodik dan sejalan dengan penelitian Muldayanti (2013), bahwa tidak terdapat interaksi antara metode belajar dan minat belajar siswa tinggi dan rendah terhadap prestasi belajar pada materi sistem pencernaan, akan tetapi keberhasilan penggunaan model pembelajaran dipengaruhi oleh minat belajar siswa.

\section{KESIMPULAN}

Setelah melakukan penelitian, perhitungan data dan pengujian hipotesis, peneliti memperoleh kesimpulan sebagai berikut : (1) Terdapat perbedaan yang signifikan hasil belajar antara siswa yang diajarkan menggunakan bahan ajar terintegrasi nilainilai islami dan yang diajarkan menggunakan 
buku ajar kimia SMA/MA pegangan siswa melalui model pembelajaran Problem Based Learning pada pokok bahasan Hidrolisis Garam. (2) Terdapat perbedaan yang signifikan sikap islami siswa sebelum dan sesudah diajarkan dengan menggunakan bahan ajar kimia terintegrasi nilai-nilai Islami. (3) Terdapat korelasi yang signifikan nilai spiritual dengan peningkatan hasil belajar siswa yang diajarkan menggunakan bahan ajar kimia terintegrasi nilai-nilai Islami pada pokok bahasan Hidrolisis Garam. (4) Terdapat pengaruh minat belajar terhadap hasil belajar siswa antara yang diajarkan menggunakan bahan ajar terintegrasi nilainilai Islami dan yang diajarkan menggunakan buku ajar kimia SMA/MA pegangan siswa pada pokok bahasan hidrolisis garam dengan Model Problem Based Learning. (5) Terdapat pengaruh jenis bahan ajar terhadap hasil belajar siswa antara yang diajarkan menggunakan bahan ajar terintegrasi nilainilai Islami dan yang diajarkan menggunakan buku ajar kimia SMA/MA pegangan siswa pada pokok bahasan hidrolisis garam dengan Model Problem Based Learning. (6) Tidak terdapat pengaruh minat belajar terhadap sikap islami siswa yang diajarkan menggunakan bahan ajar kimia terintegrasi nilai-nilai Islami pada pokok bahasan Hidrolisis Garam. (7) Tidak terdapat interaksi antara jenis bahan ajar dengan minat belajar terhadap hasil belajar siswa.

\section{DAFTAR PUSTAKA}

Arfiyah, dkk., (2016), Pengaruh Pembelajaran Problem Based Learning (PBL) Dilengkapi Dengan Kompendium Al-Qur'an Terhadap Minat Dan Prestasi Belajar Siswa (Pokok Bahasan Konsep Mol Kelas X Matematika dan Ilmu Alam (MIA) MAN 2 Madiun Semester Genap Tahun Pelajaran 2014/2015), Jurnal Pendidikan Kimia, 5(1), 96-104.

Basuki, Kaih H., (2015), Pengaruh Kecerdasan Spiritual dan Motivasi Belajar Terhadap Prestasi Belajar Matematika, Jurnal Formatif, 5(2), 120133.
Budi Lina, dkk., (2013), Pengaruh Metode Pembelajaran Group Investigation (GI) Dan Minat Terhadap Prestasi Belajar Siswa Pada Pokok Bahasan Struktur Atom Dan Sistem Periodik Kelas XI SMAN 6 Surakarta Tahun Pelajaran 2012/2013, Jurnal Pendidikan Kimia, 2 (3), 10-18.

Darmana, A., (2013), Pandangan Siswa Terhadap Internalisasi Nilai Tauhid Melalui Materi Termokimia, Makalah pada SEMIRATA MIPA UNILA, Lampung.

Darmana, A., \& Manoan Batubara., (2016), Kelayakan Bahan Ajar Kimia-Tauhid Berdasarkan Kriteria Badan Standar Nasional Pendidikan (BSNP) Dan Respon Siswa, Seminar Nasional Kimia Dan Pendidikan Kimia 2016, Medan.

Depdiknas, (2010), Pengembangan Pendidikan Budaya dan Karakter Bangsa: Pedoman Sekolah, Departemen Pendidikan Nasional, Jakarta.

Dermawan, A., (2016), Pengembangan Bahan Ajar Kimia Terintegrasi Nilai-Nilai Islami pada Pokok Bahasan Minyak Bumi, Skripsi, UNIMED, Medan.

Djudin, T., (2011), Menyisipkan Nilai-Nilai Agama Dalam Pembelajaran Sains: Upaya Alternatif Memagari Aqidah Siswa, Jurnal Katulistiwa-Journal of Islam Studies, 1(2): 151-160.

Hidayat, H., (2010), Pengaruh Minat Belajar Siswa Terhadap Prestasi Belajar Mata Diklat PDTM, Jurnal Pendidikan Teknik Mesin, 10(1): 12-15.

Hikmah, N.I., (2013), Nilai-nilai Pendidikan Karakter Dalam Proses Pembelajaran Kimia Berbasis Integrasi Sains dan Agama Pada Materi Larutan Penyangga, Skripsi, Fakultas Ilmu Tarbiyah dan Keguruan, IAIN Walisongo, Semarang.

Jumini, S., \& Wahyudi., (2015), Konsep Vektor Dan Nilai-Nilai Pendidikan Spiritual Didalamnya (Telaah Buku: "Analisis Vektor" Kajian Teori Pendekatan Al-Qur'an Karya Ari Kusumastuti), Jurnal PPKM, 1: 1-10.

Marsonet, M., (2012), Science and Religion as Conceptual Schemes, Academicus, 5: 17-25. 
Muldayanti, N.D., (2013), Pembelajaran

Biologi Model STAD dan TGT Ditinjau dari Keingintahuan dan Minat Belajar Siswa, Jurnal Pendidikan IPA Indonesia, 2 (1): 12-17.

Okmarisa, H., A. Darmana, dan R. D. Suyanti, (2016), Implementasi Bahan Ajar Kimia Terintegrasi Nilai Spiritual dengan Model Pembelajaran Problem Based Learning (PBL) Berorientasi Kolaboratif untuk Meningkatkan Hasil Belajar Siswa, Jurnal Pendidikan Kimia, 8(2): 58-63.

Rochman, C., (2010), Pembelajaran Fisika Berbasis NIlai Agama Islam pada Perguruan Tinggi Agama Islam, Jurnal Penelitian Pendidikan, 11 (2): 52-59.

Saputro, A.N.C., (2011), Pengintegrasi NilaiNilai Relegius Dalam Buku Pelajaran Kimia sebagai Metode Alternatif Membentuk Karakter Insan Mulia Pada Siswa, Seminar Nasional VIII Pendidikan Biologi, FMIPA FKIP Universitas Sebelas Maret, Surakarta.

Slameto., (2010), Belajar dan Faktor-Faktor yang Mempengaruhinya, Rineka Cipta, Jakarta.

Sugiarti, L., (2013), Pengaruh Bahan Ajar Terhadap Kualitas Hasil Belajar Materi Konstruksi Pola Pada Prodi PKK Tata Busana, Jurnal FFE, 2 (1): 48-54.

Trianto, (2010), Mendesain Model Pembelajaran Inovatif-Progresif , Kencana, Jakarta. 